\section{"PROVISION FOR YOUNG IMBECILES."}

To the Editors of THE LANCWT.

SIRS, - -I should like to add my support to the opinions expressed on this subject by Dr. Shuttleworth and Miss Twining. During the time that I was at the Darenth Schools for Imbecile Children I repeatedly had to refuse admission to imbecile children in various parts of Inngland because the parents did not live in London, residence in the metropolis being necessary to secure reception of their children. Since leaving the sehools, and more especially since my connexion with a London hospital for nervous diseases, I have come into contact with a large number of cases whose parents or medical attendants wished them to be admitted into an institation in order that the children might be suitably educated and trained, but I have been obliged in too many cases to say that no accommodation could be found. There is no donbt that there are very many imbecile children scattered throughout the country for whom training schools should be provided, and my opinion on this point is strengthened on reading the return recently made by order of Sir Walter Foster as to the number of imbecile and epileptic children under sixteen years of age in each workhouse, separate infirmary, school, or other similar establishment belonging to the guardians of unions in England and Wales (excluding the metropolis). It is a lamentable fact that England-which is foremost in charitable and philanthropic enterprise-lags so far behind other countries in its provision for these unfortunate children. Our American cousins are usually wideawake and not disposed to throw away their money, and yet in America there are fifteen or sixteen institutions for providing education and training, while we in Fingland are content with six. Plenty of money is spent year by year in building asylums for the insane or adding to the accommodation already existing, and yet hardly anything is done for the training of these children. To allow the educable cases to remain in unions, where no provision for teaching is made, is a bad and expensive policy. This fact requires to be brought home to the minds of guardians and others whose business it is to look after these children, and it should be demonstrated to them that it is quite as necessary and important to make provision for javenile imbeciles as for the insane.

I am, Sirs, yours faithfully,

FLETCHER BEACH, Formerly Medical Superintendent of the Darenth Schools

Kingston-hill, S.W., April 29th, 1895.

\section{"THE WOMEN'S FREE HOSPITAL, SOUTHAMPTON." \\ To the Editors of THE LANCET.}

SIRS,-The letter in THE LANChT of to day from the Medical Society requires a few words of reply, and for many reasons it is fitting they should come from me. It must first of all be noticed by everyone who has carefully read the letters of this society that the charges they have formulated against the hospital and its officers have undergone frequent changes, the most notable of which occurs in Paragraph 1, in which the words used up to the present, "appalling frequency," degenerate into " unusual frequercy." "Ihis is must satisfactory, and I am glad the society has seen fit to alter its verbiage. I do not know even now that the words " unusual frequency" are entirely fitting when the facts are considered. When I began first to know Sonthampton intimately from residence in its neighbourhood I was asked to see a number of patients in consultation and to do a number of operations. I was not surprised to find a large proportion of cases of bad pyosalpinx, for Southampton is just the kind of place where I should have expected to find them. But I was surprised to find that no effort whatever had been made effectually to treat these cases as they must be treated, and I could not discover that any ever had been so treated at the Royal South Hants Infirmary. I urged the establishment of a special hospital first on Mr. J. F. Bullar, who had been one of $m y$ post-graduate pupils, and then upon Mr. Kliot. The former gentleman elected to follow another special line of practice by opening an ophthalmic hospital. Mr. Tiliot followed my advice, and I took no small pains to do all I could to help him towards success, and I am glad to feel that I have succeeded. I operated on a large number of cases, scme in
Southampton, many more in Birmingham. If all these bad been included in Mr. Eliot's list their number in ration might have, indeed, setmed to be "appalling," but they were merely the accumulation of the neglect of years. I attended meetings of the Southampton Medical Sociery, I showed specimens of Fallopian bags of pus fresh from Soutbampton patients, I did my best to instrnct my audience in the diagnosis and treatment of such casessome if not the whole of the surgical staff of the infirmary were present-but $u p$ to the present day it would seem as if gonorrbœa and its products were onknown in Southampton so far as the infirmary is concerned, for not a case of damaged appendages is yet recorded as having been dealt with there. There may be, yet I know that in spite of all my warnings and preaching against what has most erroneously been termed "Tait's operation" there has been a removal of uterine appendages far too widely extended. Hardly a month of my life passes in which I bare not at least once to interfere and prevent an operation being performed, and it is very likely that I have given my vote against proposals of the kind at Southampton. This has happened in a number of cases at Southampton, and this fact goes to prove not only that I exercised the repressive inflaence which all consultants similarly placed must occasionally be called upon to exercise, but that Mr. Eliot loyallp abided by my advice. Some of these cases the members of the Southampton Society have hunted up, and they pervert, or wish to pervert, the legitimate inference to be drawn from them. That early experierce will conclude for the necessity of operation and that maturer experience will decide against it is the fact of most striking importance in the whole history of such operations as strabismus, excision of joints, \&c. If it were not so, what would be the good of extending experience? There may be yet, as there have been, errors of commission; but are those who deliberately and persistently sin by omission to have no word raised against them? I assert that the greatest possible care has been nsed in the practice of the Women's Hospital at Southampton to avoid errors of commission, and the fact that the Medical Society of Southampton decline to hear the details of all the cases performed there read before them and be themselves the judges shows that they know this to be true. However, such a paper will be read before the British Gynacological Society, and then I challenge the members of the Southampton $M \in d i c a l$ Society to produce any evidence they may have to the contrary.

One word as to the resignation of "four non-resident members of the society" arising directly from this issoe. From the lightsome way in which this resignation is spoken of your readers might be led to regard it as of no consequence. They are "non-resident" members in the sense that they do not dwell within the borongh of Southampton, but they were the four most disting aished members of the society, four members of the staff of the neighbouring Government Medical School at Netley, quite closely enongh resident to know all the facts-men of position and knorledge to be able to judge correctly, so completely free from local prejudice as to give an unbiased judgment and to satisfy themselves of the real basis of all the complaints. I am, Sirs, yours truly,

Birmingham, April 27th, 1895.

LAWSON TAIT.

\section{To the Editors of THE LANCET.}

Srns, - The committee of the Women's Hospital are at one: with the Medical Society in the determination, as expressect in their last letter, to avoid a newspaper correspondence, and this communication is the last they will make on the subject at issue.

They emphatically decline, as in the beginning, to recognise. the claim of the Medical Society to interfere in the affairs of the hospital, holding as they do the opinion that its action bas arisen only from a "mean and despicable jealonsy," utterly apart from any true regard for the interests. of the profession or for the welfare of the sick-a. fact now thoroughly appreciated in Sonthampton. If complaints bad reached them in any legitimate manner, such as from patients (or their friends) who had been treated in the hospital, or from subscribers to the charity, or from leading members of the profession, unbiased by local influ.. ences, they would bave at once removed any defects bronght to notice ; but not a single complaint from any one of these. sources bas been made. The committee, therefore, restirg their case on the integrity of their actions and on the weight 
of eridence that has accumulated since this correspondence commenced as to the value of the work done at the hospital, may justly ignore the attempts to injure it so persistently and unworthily made by the Medical Society.

We are, Sirs, yours faithfully,

A. F. Fo RBES, M.A., Chairman.

H. C. Phildirs, Hon. Sec.

Southampton, April 30th, 1895.

\section{To the Editors of THE LANCET.}

SIRs,--The committee of the Women's Hospital regret that Dr. Playfair should have made any mistake as to the correspondence they referred to. The committee referred to the following correspondence which took place in November, 1894 :-

[COPY.]

"Southampton Medrcat, Soctety.

"Hamilton House, Southampton. "Nov. 21st, 1894.

"DEAR SIR, - I am instructed by the committee of the above society to fortard you the enclosed copy of a letter from Dr. Playfair, consulting physician to the Women's Free Hospital, Southampton, which has been sent to Dr. Gwillim, joint hon. sec., Southampton Medical Society. Till you kindly lay it before your committee? I am instructed also to request the favour of an answer to the circular which was sent last request the favour of an

"The committee of the Southampton Medical Society think that hey may reasonably expect an answer within a fortnight, and if none received within that time they will feel justified, considering the gratity of the matter involved, in taking such further action in the watter as they may cleem expedient.

"I remain, yours faithfully,

(Signed) "Normar Aldoridge,
"Joint hon. sec. Southampton Medical Society.

"H. C. PHILlips, Esq.

Hon. Sec. Southampton Free Hospital for Women."

[COPY.]

"3l, George-street, Hanover-square, W., "Nov. 18 th, 1894.

"DRdR SIR,-I have been asked by Dr. Bullar whether in my opinion the ouestions put to the committee of the Women's Pree Hospital in Southampton, in your circular of Nov. 8th, are such as are reasonable, and should receive a full and explicit answer. To this I have no hesitation in replying fully in the affirmative. In my opinion when lestation in replying fully in the affirmative. In my opinion when quan ans as regards the working and results of such an

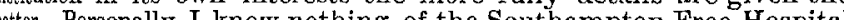
better. Personally I know nothing of the Southampton Free Hospital lor Women. When 1 was asked to becone consulting physician 1 conthat it was all that such a hospital should be

"Now that this has been called in question I am distinctly of opinion that its committee should afford every facility for a full and ample inrestigation of its working and results.-I am, faithfully yours,

$$
\text { (Signed) "W. S. PLAYFAIR." }
$$

As Dr. Playfair corresponded with the Medical Society some meeks before he wrote to his committee the committee naturally treated his latter communication in the only ranner which was open to me. The committee do not think they need repeat their views on this subject, bat would like to point out that they never attached the word "discourteous" to Dr. Playfair's correspondence, but to the manner in which he has treated them.

We are, Sirs, yours faithfully

A. F. Forbes, M.A., Chairman.

H. C. PHillips, Hon. Sec.

Southampton, April 30th, 1895.

\section{REGISTRATION OF MIDWIVES.}

To the Editors of THE LANCET.

DEAR SIRS,-Kindly oblige the guardians by publishing the enclosed.-Your obedient servant,

JNo. H. RUThergLeN, Clerk. [COPY.]

"St. Mary AbBot's, Kensington.

"Guardians' Offices, Marloes-road, Kensington, W. "April 30th, 1895.

"SIR,-The guardians of this parish, who for some years past have trained in the special lying-in wards attached to their intirmary a large number of trained nurses to pass the examination of the London Otstetrical Society, have heard with much regret of the resolution Dassed by the General Medical Council on Dec. 3rd last with respect to the issue of midwifery diplomas or certificates in general, and of the certificates of the Obstetrical Society of London in particular. The gtardians are the more surprised at this action as they have always understood that the General Medical Council have regarded the a)sente of public provision for the education and supervision uf midwives as being productive of a large amount of suffering and disease among the poorer classes, and that the Councl had been recommended by a Select Committee of the Hotise of Commons to frame rules for the conduct of examinations dirires. It was to a great extent to meet these expressions of chinion that the guardians of this parish undertook, in conjunction k.tif tat Workhouse Infirmary Nursing Association, the yearly training of a number of previously qualified nurses in their midwifery wards, but they have every reason to fear that if the resolution of the Council its its present form its diploma or certificate of competeney, the good work which they have been doing for so many years will cease, as women will be be unable to obtain a certificate of efficiency, qualifying them to act as midwives. Having regard, therefore, to the value and importance which is attached to special training in midwifery, and to the examinations cenducted by the London Obstetrical Society and other bodies, the guardians have directed me to ask that the General Medical Council will reconsider and withdraw their resolution of December last, so that the training and sending out of competent midwives may be continued unimpeded. "I am, Sir, your obedient servant,

"The Registrar, General Medical Council, "299, Oxford-street, W."

\section{"DEGREES OF KNEE-JERK."}

To the Editors of THE LANCET.

SIRs, - Will you kindly give me a few lines of your space to make a slight addition to an article under the above title in THE LANCET of March 30th, 1895? In the last sentence but one, on p. 802, I expressed a hope that someone would invent an instrument which should enable us to measure the degree of any given jerk. My attention has been drawn to an article by Dr. Ewen Maclean in the Bristol MedicoChirurgical Journal for March, 1892, in which he describes and figures such an instrument ; he calls it a "jactometer," and it was made for him by Messrs. Down Bros., of London. His instrument fulfils so completely the three requirements I mentioned in my article that I think I must have heard or read of his invention before I wrote the article. If so, I had quite forgotten all about it, and I know $I$ had not read his paper when my article appeared. I have not yet had an opportunity of seeing it in working, but I hope that all who are interested in the knee-jerk will read his paper and if possible try his instrument. It appears to me to be very ingeniously constructed.

London, April 30th, 1895. I am, Sirs, yours faithfully,

LEONARD J. KIDD.

\section{"A CASE OF EQUINIA (GLANDERS); RECOVERY." \\ To the Editors of THE LANCET.}

Sirs, - In ThE LANCET of March 16th Mr. T. W. H Garstang records, under the above heading, a supposed case of glanders in a veterinary surgeon. The patient was thought to have contracted the disease while treating a horse affected with "nasal catarrh of a suspicious type," but, strange to say, both man and horse ultimately recovered. It appears to me that this fact throws grave doubts on the accuracy of the diagnosis in both cases. It is admitted that recovery from glanders is exceedingly rare in man, and in the horse it is essentially a fatal disease. I am not aware that there is any recorded case of recovery from glanders. Owing to the difficalties of making an accurate diagnosis in certain cases in the horse, cases of "nasal gleet" have in times past been mistaken for the specific disease, and on their recovery it has been claimed that they were genuine cases of glanders, but I do not think any authentic case of glanders has ever been known to recover. It is not for me to question the accuracy of Mr. Garstang's diagnosis in his case, but I should like to make a few observations on the opinions expressed by his patient on the subject of glanders in the horse. I have no means of knowing who the veterinary surgeon is, or whether he is a member of the Royal College of Veterinary Surgeons, or only a registered practitioner without any qualification, but it seems evident, from the statement attributed to him in Mr. Garstang's article, that he has not kept himself acquainted with the latest knowledge on the important question of glanders. He is reported to have said that glanders always commences with nasal gleet, from which the animal may recover; but that when the gleet runs on to glanders or farcy recovery is impossible." In this statement appears the confusion I have referred to above. Chronic nasal catarrh or nasal gleet cannot run on to glanders. It is a non-specific disease affecting the mucous membrane lining the nasal passages and sinuses. It is often very difficult to treat, and usually proved most obstinate, but recovery may and frequently does take place. There can be no connexion between the local affection known as nasal gleet and the fatal specific disease glanders. Glanders begins with a discharge from the nasal passages, followed by other symptoms specially characteristic of the disease-ulceration 